\title{
ENVIRONMENTAL FACTORS AND REPRODUCTION IN THE FEMALE HOPPING MOUSE, NOTOMYS ALEXIS
}

\author{
W. G. BREED \\ Department of Anatomy, University of Adelaide, Adelaide, \\ South Australia 5000
}

(Received 6th Fanuary 1975)

\begin{abstract}
Summary. Australian hopping mice (Notomys alexis) were subjected to short or long photoperiods, different social environments and/or water deprivation. The age at which vaginal opening and first oestrus occurred was delayed by short photoperiods and by the absence of male proximity. Water deprivation prevented normal maturation. The normal 7 to 8 day oestrous cycle was prolonged by short photoperiods or water deprivation. Animals deprived of water had lighter body, ovarian and uterine weights, and follicular growth seemed to be impaired. No differences in organ weights were found between animals in the two photoperiods. The significance of the findings is discussed.
\end{abstract}

\section{INTRODUCTION}

The Spinifex hopping mouse (Notomys alexis) is one of several murid rodents that occurs in the arid centre of Australia. Unlike native mice of the genus Pseudomys, hopping mice have external anatomical features that are similar to those of the desert-adapted rodents of North America such as kangaroo rats (Heteromyidae) and of Africa and Asia such as gerbils (Cricetidae) and jerboas (Dipodidae). Hopping mice are usually found on stabilized sand hills; they are larger than house mice (Mus musculus) and have characteristic specializations of the locomotor system for saltation, e.g. long legs, feet and tail. The kidney has been shown to concentrate urine so that water loss is minimized (MacMillen \& Lee, 1969).

In the temperate regions of the world, it has been clearly shown that most, if not all, species of murid rodents have a restricted breeding season which is usually regulated photoperiodically (Baker \& Ranson, 1932; Lecyk, 1963; Clarke \& Kennedy, 1967; Breed \& Clarke, 1970; and for detailed review see Sadleir, 1969). The social environment also has some effect, however, and breeding may extend into the winter months in special circumstances (Christian, 1971).

In the desert, environmental conditions are much less predictable than in temperate regions because of the spasmodic and infrequent occurrence of rain. After periodic rain extensive growth of vegetation occurs and the flowering of 
many plant species takes place. Desert rodents feed largely on seeds (Finlayson, 1940; Watts, 1970); their food therefore varies erratically and its abundance is not likely to be correlated with any specific time of year. Little is known about the breeding of hopping mice, but Finlayson (1940) considers that reproduction is not seasonal and follows periods of rain whenever this occurs. A study has, therefore, been initiated to investigate in more detail the breeding of hopping mice in the wild and in captivity. In this paper, data on time of vaginal opening, first oestrus and details of the oestrous cycle are presented, together with the effects of different photoperiods, male proximity and water deprivation on these parameters. Some preliminary results have previously been given in abstract form (Breed, 1974, 1975).

\section{MATERIALS AND METHODS}

\section{General}

Animals were first collected in the wild in the winter of 1968 (Smith et al., 1972) from Yuendumu, Northern Territory. Most of the animals used in the present experiments are progeny of these individuals that had previously been kept either at the Waite Agricultural Research Institute, the Genetics Department, University of Adelaide, or the Institute of Medical and Veterinary Science, Adelaide.

The stock animals were kept as individual pairs in plastic cages $(25 \times 15 \times 40$ $\mathrm{cm}$ ) in a $14 \mathrm{hr}$ light:10 hr dark (14L:10D) photoperiod (lights on 08.00 to 22.00 hours) and were fed a mixed seed diet (see below) and commercial Oxoid pellets. The room temperature was kept at about $22^{\circ} \mathrm{C}$ but was higher during the day in the summer months. No other species were kept in the same room.

Smith et al. (1972) reported that young could be weaned at Day 24, but will suckle until about Day 30 of age. Thus, in the present study the mice were weaned 1 month after birth. Initial observations indicated that vaginal perforation had not occurred by this time and that subsequent survival was good.

The experimental animals were randomly allocated to the various treatments of Exps 1 to 5 as they became available. The cupboards, $1.8 \times 0.6 \times 0.6 \mathrm{~m}$, were wooden and lightproof; each was fitted with two fluorescent strip lights (40 W each) placed $45 \mathrm{~cm}$ apart and set to give a lighting regimen of 16L:8D (long photoperiod:lights on 07.00 hours) or $6 \mathrm{~L}: 18 \mathrm{D}$ (short photoperiod:lights on 08.00 hours). Since seed is the main diet of this species in the wild, the experimental animals were fed a mixture of pennicum seed:canary seed: Japanese millet $(3: 2: 1)$. Unless otherwise indicated, females were examined daily for vaginal perforation and vaginal smears were then taken daily since the vagina remained patent. Animals were killed by cervical dislocation and the ovaries and uteri were immediately removed and weighed. Serial sections of ovaries were subsequently cut at $7 \mu \mathrm{m}$, stained with haematoxylin and eosin, and all CL measured with a micrometer eyepiece so that the mean of the two largest diameters could be obtained for the average maximum diameter. The 
histological appearance was also noted. Sizes of all Graafian follicles greater than $400 \mu \mathrm{m}$ in diameter were determined and recorded by taking two diameters at right angles through the section that contained the oocyte nucleus. Representative $7 \mu \mathrm{m}$ sections of uteri and vaginae were also obtained. Statistical analyses were performed by unpaired $t$ tests.

\section{Experimental procedures}

Experiment 1 . At weaning, female mice only were placed in the cupboards in a room apart from the breeding colony, and no other animals were present. The females were subjected to long or short photoperiods and all had free access to water. The mice were checked at least twice/week for vaginal perforation. The experiment lasted 70 days.

Experiment 2. At weaning, female mice were placed in cupboards in the same room as the breeding colony. Adult males, although in separate cages, were also placed in the cupboards and all the animals were subjected to long or short photoperiods. Water was freely provided. The experiment lasted 90 days.

Experiment 3. When a pregnant female gave birth in the breeding colony, she and her litter were placed in a cupboard in the animal room and subjected to long or short photoperiods. The young were weaned at 30 days of age by returning the parents to the breeding colony and leaving the young females in the cupboard in which adult males were also present. Water was freely available. At 80 days of age, water was withheld from some of the females and all the animals were killed when 100 days old.

Experiment 4 . At weaning, females were placed in cupboards in the same room as the breeding colony, and subjected to long or short photoperiods. Water was freely available and no males were present in the cupboards. After first oestrus had occurred, individuals were replaced in the breeding colony.

Experiment 5. Adult females, of unknown age and reproductive history, were subjected to long or short photoperiods in cupboards in the breeding colony room; some individuals were allowed free access to water, whereas others were given none. Vaginal smears were taken daily for 28 days, and then the experiment was terminated.

\section{RESULTS}

Time of vaginal opening and first oestrus

None of the females in Exps 1 to 4 had a perforate vagina when placed in the cupboards. The times at which perforation occurred are shown in Table 1.

When no males were present in the cupboards (Exps 1 and 4), vaginal perforation occurred later than when males were present (Exps 2 and 3). This appeared to be true for both lighting regimens. The absence of males in Exp. 4 appeared to have an effect on the time of first oestrus although the difference was not significant. The length of the photoperiod significantly affected the time of vaginal opening. In females kept in the short photoperiods, vaginal opening occurred at a significantly greater age than in the animals kept in the long photoperiod in two of the four experiments. A similar trend also seemed to be true for the time of first oestrus. 
Table 1. The effect of various photoperiods and presence of the male on the time of vaginal opening and first oestrus in hopping mice

\begin{tabular}{cccc}
\hline & & \multicolumn{2}{c}{ Age (days after birth) at: } \\
\cline { 4 - 5 } Treatment $\dagger$ & $\begin{array}{c}\text { No. of } \\
\text { animals }\end{array}$ & Vaginal opening & First oestrus \\
\hline Experiment 1 & & & \\
16L:8D & 4 & $51 \cdot 5 \pm 4 \cdot 1 * *$ & - \\
6L:18D & 4 & $65 \cdot 5 \pm 1 \cdot 2$ & - \\
Experiment 2 & & & \\
16L:8D & 6 & $43 \cdot 2 \pm 2 \cdot 4$ & $58 \cdot 8 \pm 4 \cdot 7$ \\
6L:18D & 6 & $46 \cdot 0 \pm 3 \cdot 1$ & $61 \cdot 0 \pm 5 \cdot 0$ \\
Experiment 3 & & & \\
16L:8D & 8 & $40 \cdot 7 \pm 1 \cdot 2 * * *$ & $45 \cdot 6 \pm 2 \cdot 9 *$ \\
6L:18D & 7 & $50 \cdot 4 \pm 2 \cdot 8$ & $64 \cdot 3 \pm 7 \cdot 4$ \\
Experiment 4 & & & \\
16L:8D & 9 & $52 \cdot 3 \pm 5 \cdot 4$ & $59 \cdot 8 \pm 4 \cdot 9$ \\
6L:18D & 8 & $60 \cdot 1 \pm 3 \cdot 4$ & $68 \cdot 4 \pm 2 \cdot 7$ \\
\hline
\end{tabular}

Values are means \pm S.E.M.

$* P<0.05 ; * * P<0.02 ; * * * P<0.01$.

$\dagger$ See text for details of experiments.

Vaginal smears

In most animals marked cyclic changes occurred in the vaginal smears. The cycle could be divided into three stages: pro-oestrus (predominantly nucleated epithelial cells and no leucocytes), oestrus (predominantly cornified cells and no leucocytes), and dioestrus (predominantly leucocytes either with nucleated epithelial and/or cornified cells). The cycle lengths for the females in the various experiments are given in Table 2. In animals supplied freely with water and

Table 2. Effect of photoperiod, male presence, and water deprivation on the various stages of the oestrous cycle of hopping mice

\begin{tabular}{|c|c|c|c|c|c|c|c|c|}
\hline \multirow{2}{*}{$\begin{array}{l}\text { Exp. } \\
\text { no. }\end{array}$} & \multirow{2}{*}{ Photoperiod } & \multirow{2}{*}{ Water } & \multirow{2}{*}{$\begin{array}{c}\text { No. of } \\
\text { animals }\end{array}$} & \multirow{2}{*}{$\begin{array}{l}\text { No. of } \\
\text { cycles }\end{array}$} & \multicolumn{4}{|c|}{ Length (days) } \\
\hline & & & & & Pro-oestrus & Oestrus & Dioestrus & Total cycle \\
\hline 1 & $\begin{aligned} 16 \mathrm{~L} & : 8 \mathrm{D} \\
6 \mathrm{~L} & : 18 \mathrm{D}\end{aligned}$ & $\begin{array}{l}+ \\
+\end{array}$ & $\begin{array}{l}4 \\
4\end{array}$ & $\begin{array}{r}12 \\
6\end{array}$ & $\begin{array}{l}0.9 \pm 0.3 \\
1 \cdot 2 \pm 0.5\end{array}$ & $\left.\begin{array}{l}1 \cdot 6 \pm 0 \cdot 3 \\
7 \cdot 6 \pm 2 \cdot 0\end{array}\right\} *$ & $\begin{array}{l}5 \cdot 2 \pm 0.5 \\
6 \cdot 2 \pm 1 \cdot 7\end{array}$ & $\begin{array}{r}7 \cdot 7 \pm 0 \cdot 5 \\
15 \cdot 1 \pm 3 \cdot 4\end{array}$ \\
\hline 2 & $\begin{aligned} 16 \mathrm{~L} & : 8 \mathrm{D} \\
6 \mathrm{~L} & : 18 \mathrm{D}\end{aligned}$ & $\begin{array}{l}+ \\
+\end{array}$ & $\begin{array}{l}6 \\
6\end{array}$ & $\begin{array}{l}23 \\
22\end{array}$ & $\begin{array}{l}0.5 \pm 0.2 \\
0.4 \pm 0.2\end{array}$ & $\begin{array}{l}2 \cdot 7 \pm 1 \cdot 1 \\
1 \cdot 4 \pm 0.4\end{array}$ & $\begin{array}{r}5 \cdot 8 \pm 0 \cdot 6 \\
12 \cdot 8 \pm 5 \cdot 3\end{array}$ & $\begin{array}{r}8 \cdot 8 \pm 0 \cdot 7 \\
14 \cdot 6 \pm 4 \cdot 7\end{array}$ \\
\hline \multirow[t]{2}{*}{3} & $\begin{array}{l}16 \mathrm{~L}: 8 \mathrm{D} \\
16 \mathrm{~L}: 8 \mathrm{D}\end{array}$ & $\stackrel{+}{-}$ & $\begin{array}{r}10 \\
4\end{array}$ & $\begin{array}{r}64 \\
4\end{array}$ & $\begin{array}{l}0.5 \pm 0.1 \\
0.5 \pm 0.2\end{array}$ & $\begin{array}{l}1 \cdot 8 \pm 0.3 \\
2 \cdot 7 \pm 0.7\end{array}$ & $\left.\begin{array}{r}6 \cdot 2 \pm 0 \cdot 6 \\
13 \cdot 3 \pm 1 \cdot 2\end{array}\right\} * *$ & $\left.\begin{array}{r}8 \cdot 4 \pm 0 \cdot 7 \\
16 \cdot 3 \pm 0.7\end{array}\right\}$ \\
\hline & $\begin{array}{l}6 \mathrm{~L}: 18 \mathrm{D} \\
6 \mathrm{~L}: 18 \mathrm{D}\end{array}$ & $\stackrel{+}{-}$ & $\begin{array}{l}7 \\
3\end{array}$ & $\begin{array}{r}51 \\
5\end{array}$ & $\begin{array}{l}0.2 \pm 0.1 \\
0.5 \pm 0.5\end{array}$ & $\begin{array}{l}1.8 \pm 0.4 \\
1.8 \pm 0.8\end{array}$ & $\begin{array}{r}8 \cdot 3 \pm 2 \cdot 3 \\
12 \cdot 0 \pm 3 \cdot 5\end{array}$ & $\begin{array}{l}10 \cdot 3 \pm 2 \cdot 1 \\
14 \cdot 0 \pm 3 \cdot 0\end{array}$ \\
\hline $5(a)$ & $\begin{array}{l}16 \mathrm{~L}: 8 \mathrm{D} \\
16 \mathrm{~L}: 8 \mathrm{D}\end{array}$ & \pm & $\begin{array}{l}3 \\
4\end{array}$ & $\begin{array}{r}16 \\
9\end{array}$ & $\begin{array}{l}0.8 \pm 0.2 \\
1.0 \pm 0.8\end{array}$ & $\begin{array}{l}3 \cdot 6 \pm 0 \cdot 9 \\
4 \cdot 2 \pm 1 \cdot 2\end{array}$ & $\begin{array}{r}3 \cdot 4 \pm 0 \cdot 8 \\
17 \cdot 8 \pm 3 \cdot 3\end{array}$ & $\begin{array}{r}8 \cdot 0 \pm 1 \cdot 2 \\
22 \cdot 5 \pm 4 \cdot 8\end{array}$ \\
\hline 5 (b) & $\begin{array}{l}6 \mathrm{~L}: 18 \mathrm{D} \\
6 \mathrm{~L}: 18 \mathrm{D}\end{array}$ & \pm & $\begin{array}{l}4 \\
3\end{array}$ & $\begin{array}{l}6 \\
4\end{array}$ & $1 \cdot 1 \pm 0 \cdot 7$ & $\begin{array}{l}1 \cdot 1 \pm 0.8 \\
1.7 \pm 0.9\end{array}$ & $\left.\begin{array}{r}5 \cdot 2 \pm 1.9 \\
18 \cdot 0 \pm 0.5\end{array}\right\} * *$ & $\left.\begin{array}{r}7 \cdot 7 \pm 2 \cdot 3 \\
19 \cdot 7 \pm 0.3\end{array}\right]$ \\
\hline
\end{tabular}

Values are means \pm S.E.M. + , water present, - , water withdrawn.

$* P<0.05 ; * * P<0.01$. 


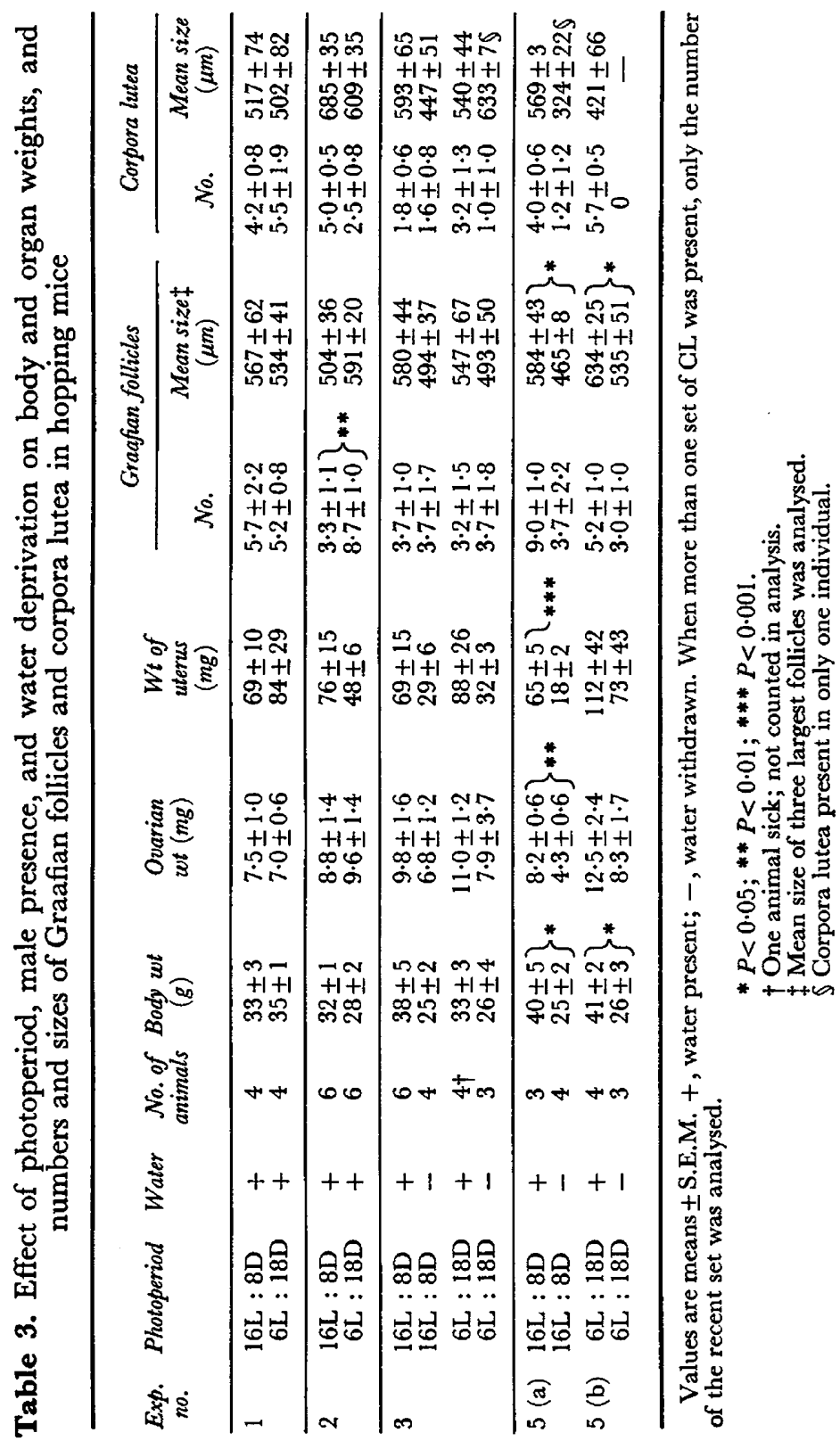


kept in the long photoperiod, an average cycle length of about 8 days occurred, regardless of whether males were present or not. Females in short photoperiods and with free access to water, except those in Exp. 5, tended to have longer cycles. In Exp. 1 this was largely due to prolonged oestrus, whereas in Exps 2 and 3 it was due to prolonged dioestrus. Water deprivation resulted in increased cycle length (Exps 3 and 5) due to an increase in the dioestrous period.

\section{Organ weights}

Table 3 shows that there was no effect of the two light regimens on organ weights at autopsy. The large variation in uterine weights is probably due to animals being killed at a specific date after the start of the experiment, irrespective of the stage of the oestrous cycle. Water deprivation had marked effects on organ weights. Body weights were significantly depressed in Exps 5 (a) and 5(b), and ovarian and uterine weights significantly depressed in Exp. 5(a), but not in Exps 3 and 5(b), although there was a tendency for reduced weights in these groups also.

\section{Ovarian histology}

Graafian follicle. The numbers and sizes of Graafian follicles are shown in Table 3. In females deprived of water, there were no significant differences in the numbers of follicles, but the average maximum size was less, although this difference was only significant in Exps 5(a) and 5(b).

Corpora lutea and luteinized follicles. Usually, 2 or 3 sets of $\mathrm{CL}$ were present in the ovaries of animals supplied freely with water. Animals in long photoperiods and provided with water in Exps 1,2 and 5 had an average of four to five large CL measuring 500 to $700 \mu \mathrm{m}$ (see Pl. 1, Fig. 1). Females in Exp. 3 had fewer CL although their sizes were similar. No CL were seen in the ovaries of $10 / 14$ mice deprived of water, but up to four unluteinized follicles were present. These structures had inner granulosa-like cells with no blood capillaries or connective tissue cells between them, and a well-developed theca interna around the periphery (Pl. 1, Fig. 2). No oocytes were seen in serial sections through such structures although checking was performed with care. The histology and cytology of the normal luteinized and involuting CL were similar to those described for other rodents, such as the mouse, rat, and vole.

\section{DISGUSSION}

The hopping mouse is probably an opportunistic breeding species (Finlayson, 1940), although well documented evidence of this is still lacking. The species occurs in much of the arid interior of Australia where environmental conditions vary between years and at the same time in different years. Smith et al. (1972) state that hopping mice can breed at 12 weeks of age and this is the age at which first litters are born in our colony. The present results show that if males are in close proximity to females and the animals are subjected to long photoperiods, vaginal perforation occurs at about 40 days of age and first oestrus a week or two later. Isolation from males and/or short photoperiods delays vaginal perforation. 

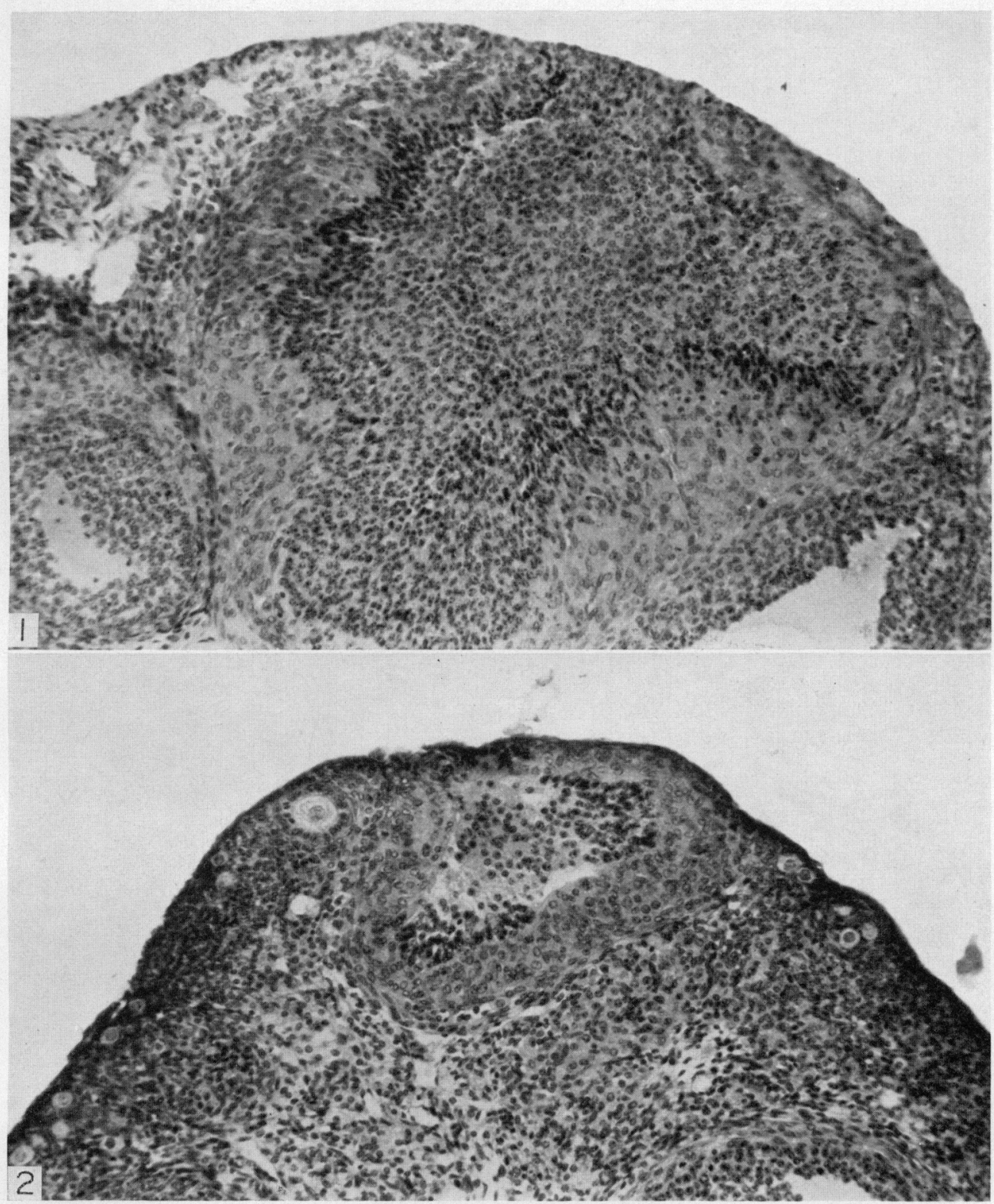

Fig. 1. Corpus luteum present in a female hopping mouse in carly diocstrus. Compare with unhuteinized follicle shown in Fig. 2. Tote hypertrophied theca interna around the periplacry and lack of obvious lutemization of inner cells at this stage. $\times 150$.

Fic. 2. Unluteinized follicle present in a female that had been deprived of water for 28 days before autopsy. Note the much smaller size than recently formed CI. (Fig. 1), hypertrophied theca interna, untransformed inner cells and indication of a small passage to outside of ovary, suggesting that the oocyte may have been released. $\times 1,50$.

(Facing p. 278) 
The presence of the male has been shown to affect the age at which vaginal perforation and first oestrus occur in laboratory mice, and additional experiments have shown that such an effect is brought about by pheromones and can be eliminated if males are castrated (Vandenbergh, 1969, 1973). It is not yet known how widespread such effects are among mammals, although male presence accelerates vaginal opening in at least two species of hystricomorph rodents (Weir, 1973a, b).

Prolonged water deprivation had a progressive effect on most adult and immature hopping mice. Adult females killed 20 to 30 days after withdrawal of water had low body weights and most individuals appeared emaciated although otherwise generally healthy. It is apparent that, under the conditions of the present experiments, in which the diet consists only of dried seeds, most individuals cannot survive indefinite water deprivation, since $6 / 8$ weanling females died between 25 and 60 days later in an experiment not detailed above. Of the two animals that survived, one never became perforate and the other, although becoming perforate, never showed vaginal oestrus. When water was given to six adult females that had previously been deprived of water for 20 days, rapid gain in body weight occurred and 7 to 8 day oestrous cycles were resumed. The marked effect of water deprivation was surprising in the light of the findings of MacMillen \& Lee (1969) which have shown that hopping mice concentrate urine to a greater degree than any other species of desert rodent so far investigated.

One of the interesting features of the reproductive biology of this species is the fairly long oestrous cycle. Females in Exps 1 to 3 had not had physical contact with males since weaning and, since CL were almost invariably present in the ovaries, it can be concluded that spontaneous ovulation regularly occurs in this species regardless of whether males are in close proximity (Exps 2 and 3 ) or whether the females are isolated in a room well away from any males (Exp. 1). In the present experiments, the animals on long photoperiods with access to water usually had an oestrous cycle of 7 or 8 days. This finding generally agrees with that of Smith et al. (1972) who found a mode of 6 days (range 4 to 8). The cycle length is considerably longer than that of the hamster (Parkes, 1931), rat (Long \& Evans, 1922) and mouse (Allen, 1922) and may be a characteristic of the genus Notomys (Watts, 1974; Crichton, 1974). Inspection of Table 2 shows the durations of the pro-oestrous and oestrous periods are similar to those of the common laboratory rodents, but the dioestrous period is prolonged. Preliminary experiments suggest that the CL are functional during the cycle since mucified vaginal epithelium occurs late in dioestrus (W. G. Breed, unpublished observations). The jerboa is an induced ovulator (Ghobrial \& Hodieb, 1973), whereas the gerbil probably ovulates spontaneously (Marston \& Chang, 1965) and, from behavioural tests, appears to have a short 4-day cycle (Barfield \& Beeman, 1968). From these limited data, therefore, it appears that rodents living in different continents but similarly adapted morphologically for desert life have different types of oestrous cycle, indicating that there is no great selection for one particular type of cycle for all species in this environment.

Hopping mice subjected to short photoperiods exhibited similar oestrous cycles to those on long photoperiods, although there was a tendency for the 
cycle length to be prolonged. The absence of males did not appear to affect the cycle length as it does in house mice (Whitten, 1958). It was apparent that photoperiod had no marked effect on ovarian or uterine weight. This is in marked contrast to voles, in which short photoperiods inhibit normal growth of both ovaries and uteri and long photoperiods allow female reproductive organs to develop (Baker \& Ranson, 1932; Lecyk, 1963; Clarke \& Kennedy, 1967; Breed \& Clarke, 1970). In the experiments of Breed \& Clarke (1970), the treatment period was about the same as for that used for the hopping mice in Exp. 1. It appears, therefore, that once vaginal perforation has occurred, ovarian activity in the hopping mouse is more independent of the lighting regimen than it is in the vole. In the vole, photoperiod probably acts so that breeding only occurs at a time of the year when food is plentiful for the rearing of young. It may be that, from the adaptive viewpoint, one should consider species to be continuous breeders and that regular seasonal anoestrus is only induced when adverse environmental conditions occur at a predictable time each year (as in voles during the winter). In deserts, harsh environmental conditions do not take place at the same time each year, and marked changes in reproductive function correlated with annual changes in environment, such as photoperiod, would be of little use for the survival of the species. Under such conditions, it is necessary for animals to respond to other environmental cues, e.g. the occurrence of rain, ground water, or the resultant changes in vegetation that occur. Preliminary experiments with supplementary diets, including Oxoid cubes, green vegetables and fruit, have not indicated any effect on the age at which puberty occurs or oestrous cycle length. It is clear, however, that water deprivation prevents individuals from having normal oestrous cycles and uteri tend to become atrophied. Prolonged dioestrus sets in, and ovarian histology shows that normal development of follicles is probably impaired, and unluteinized follicles are frequent. From the histological appearance and cellular arrangement of the unluteinized follicles it is likely that oocytes had been released, since it was sometimes possible to see a small continuation of the slitlike antrum with the outside of the ovary. It appears, therefore, that these follicles were derived from vesicular follicles but that luteinization did not occur with the release of the oocytes. Similar structures have previously been described for the plains viscacha (Weir, 1971). One or two unluteinized follicles, similar to those described above, were found in 10/19 mice in long photoperiods in Exps 1 to 5 and given water freely. They occurred in addition to CL of normal appearance and it may be that even under normal conditions not all follicles that ovulate subsequently undergo hypertrophy and luteinization in this species. Lack of follicular development suggests that water deprivation may reduce or inhibit FSH secretion, but the mechanism which brings this about is unknown. The relevance of the above results to ovarian activity in the natural environment has yet to be ascertained, but work to that end is now in progress.

\section{ACKNOWLEDGMENTS}

I should like to thank Dr C. H. S. Watts for the supply of some of the animals and Miss M. Crow and Miss A. Berry for their invaluable technical assistance. 


\section{REFERENGES}

Allen, E. (1922) The oestrous cycle in the mouse. Am. F. Anat. 30, 297-371.

BAKER, J.R. \& Ranson, R.M. (1932) Factors affecting the breeding of the field mouse (Microtus agrestis). Proc. $R$. Soc. B 110, 313-322.

Barfield, M.A. \& Beeman, E.A. (1968) The oestrous cycle in the Mongolian gerbil, Meriones unguiculatus. F. Reprod. Fert. 17, 247-251.

BREED, W.G. (1974) Environmental effects on the female reproductive organs of the Australian hopping mouse (Notomys alexis). F. Anat. 118, 387-388.

BReED, W.G. (1975) Effect of photoperiod and male presence on ovarian activity in the hopping mouse. F. Anat. (in press).

BREED, W.G. \& Clarke, J.R. (1970) Effect of photoperiod on ovarian function in the vole (Microtus agrestis). F. Reprod. Fert. 23, 189-192.

CLARKE, J.R. \& KENNEDY, J.P. (1967) Effect of light and temperature upon gonad activity in the vole (Microtus agrestis). Gen. E compar. Endocr. 8, 474-488.

Christian, J.J. (1971) Population density and reproductive efficiency. Biol. Reprod. 4, 284-294.

CRichton, E.G. (1974) Aspects of reproduction in the genus Notomys (Muridae). Aust. 7. Zool. 22, $439-447$.

Frnlayson, H.H. (1940) On central Australian mammals, Part 1. The Muridae. Trans. R. Soc. S. Aust. 64, 125-136.

Grobrial, L.I. \& HodieB, A.S.K. (1973) Climate and seasonal variations in the breeding of the desert jerboa, Faculus jaculus, in the Sudan. F. Reprod. Fert., Suppl. 19, 221-233.

LECYK, M. (1963) The effect of short day length on sexual maturation in young individuals of the vole (Microtus arvalis), Pall. Zool. pol. 13, 77-86.

Long, J.A. \& Evans, H.M. (1922) The oestrous cycle of the rat and its associated phenomena. Mem. Univ. Calif. 6, 1-148.

MAcMrllen, R.E. \& LEe, A.K. (1969) Water metabolism of Australian hopping mice. Gen. Biochem. Physiol. 28, 493-514.

Marston, J.H. \& Chang, M.C. (1965) The breeding management, and reproductive physiology of the Mongolian gerbil (Meriones unguiculatus). Lab. Anim. Care 15, 34-48.

PARKES, A.S. (1931) The reproductive processes of certain mammals. 1. The oestrous cycle of the Chinese hamster. Proc. R. Soc. B 108, 138-147.

SADLEIR, R.M.F.S. (1969) The Ecology of Reproduction in Wild and Domestic Mammals. Methuen, London.

SMrth, J.R., WATrs, G.H.S. \& CRICHTON, E.G. (1972) Reproduction in Australian rodents Notomys alexis and Pseudomys australis (Muridae). Aust. Mammal. 1, 1-7.

VANDENBERGH, J.G. (1969) Male odor accelerates female sexual maturation in mice. Endocrinology 84, 658-660.

VANDENBERGH, J.G. (1973) Acceleration and inhibition of puberty in female mice by pheromones. 7. Reprod. Fert., Suppl. 19, 415-419.

WATts, G.H.S. (1970) The food eaten by some Australian desert rodents. S. Aust. Nat. 44, 71-74.

WATTs, C.H.S. (1974) The native rodents of Australia: a personal view. Aust. Mammal. 1, 109-115.

WEIR, B.J. (1971) The reproductive organs of the female plains viscacha, Lagostomus maximus. F. Reprod. Fert. 25, 365-373.

WEIR, B.J. (1973a) Another hystricomorph rodent: keeping casiragua (Proechimys guairae) in captivity. Lab. Anim. 7, 125-134.

WEIR, B.J. (1973b) The role of the male in the evocation of oestrus in the cuis, Galea musteloides (Rodentia: Hystricomorpha). F. Reprod. Fert., Suppl. 19, 421-432.

WhitTEN, W.K. (1958) Modification of the oestrous cycle of the mouse by external stimuli associated with the male: changes in the oestrous cycle determined by vaginal smears. F. Endocr. 17, 307313. 